\section{Cut animal wastage in toxicology testing}

In my view, the questionable use of animals in toxicology studies for the regulation of devices, medicines and agrichemicals is more of a concern than the inappropriate use of animal models in research (see I. A. S. Olsson and N. H. Franco Nature 523, 35; 2015).

Testing animals' reactions to commercial products still serves all too often as a formality, rather than as a considered attempt to evaluate hazards to people or the environment (see, for example, T. Hartung Nature 460, 208-212; 2009). Studies using rodents for their full lifetime continue, despite evidence that 90-day tests have the same predictive value (S. M. Cohen Toxicol. Pathol. 38, 487-501;2010).

Irreproducibility in regulatory studies is a major problem that makes risk prediction unreliable (C. Berry Toxicol. Res. 3, 411-417; 2014). This, combined with a tendency to invoke a precautionary approach in identifying putative hazards from poorly designed regulatory studies, has encouraged adherence to an established framework of testing that has stultified thinking about experimental design.

Olsson and Franco suggest that animal models are more acceptable in research if the results are relevant to humans. That is not the case in much of regulatory toxicology - a huge consumer of laboratory animals. Colin Berry London, UK. colin@sircolinberry.co.uk Competing financial interests declared: see go.nature.com/jfvlvc.

\section{Add conservation to US trade agreement}

The US Senate last month fast-tracked negotiations for the Trans-Pacific Partnership (see go.nature.com/lt2eex), one of the largest free-trade agreements in history. We fear that this could inadvertently fuel the illegal wildlife trade unless strict precautionary measures are put in place.

Last year saw vast increases in rhinoceros and elephant poaching. Liberalized trading could add to this, not least because the trade partnership includes some of the leading consumer and supplier nations of illegal wildlife. Simpler customs procedures, relaxed border controls and trade monitoring all make the smuggling of such products easier.

The agreement should contain negotiated, binding and enforceable clauses that respect international commitments to biodiversity conservation and the regulated trade of protected species. The 2009 US-Peru Trade Promotion Agreement, for example, included obligations and sanctions to uphold Peru's commitment to restrict illegal logging and wildlife trade (see, for instance, S. Jinnah and E. Morgera Rev. Eur. Comp. Int. Environ. Law 22, 324-339; 2013). Maribel Rodriguez International University of Andalusia, Baeza, Spain. Jacob Phelps Center for International Forestry Research, Bogor Barat, Indonesia; and Lancaster University, UK. jacob.phelps@gmail.com

\section{Probe effects of krill fishing and climate}

Progress in establishing marine protected areas around East Antarctica and in the Ross Sea seems to have stalled, threatening to derail research and conservation in the region. We propose temporary, experimental closures of fisheries to help to disentangle the complex effects of human activities and natural changes on populations of krill predators such as penguins, whales and fish.

The Conservation of Antarctic Marine Living Resources (CAMLR) Convention has been in force since 1982, yet the impact of krill fishing on Antarctic predators is still unclear. In the Western Antarctic Peninsula, confounded variables and the difficulties of obtaining fisheries data at small spatial scales make it hard to evaluate the relative influence of various factors on krill-predator populations. These include climate change and cetacean recovery, as well as fishing effort and other human activities.

Small-scale, temporary experimental closures have been instructive in South Africa; these operate in rotation to focus on the effects of the closure (R. B. Sherley et al. Biol. Lett. 11, 20150237; 2015). Under the convention, the use of such small experimental units has long been considered important for managing scientific study and conservation (A. J. Constable CCAMLR Sci. 9, 233-253; 2002). It mandates that its commission "shall formulate, adopt and revise conservation measures on the basis of the best scientific evidence available".

Because krill predators in the Western Antarctic Peninsula are well monitored, it makes it a priority area for testing experimental manipulations. We encourage parties to the convention to honour their commitments to Antarctic conservation by putting forward a plan for experimental closures in the region.

Tom Hart University of Oxford, UK.

Heather J. Lynch Stony Brook University, New York, USA.

Ron Naveen Oceanites, Chevy

Chase, Maryland, USA.

tom.hart@zoo.ox.ac.uk

\section{Climate law: Dutch decision raises bar}

A District Court in The Hague ruled last month that the government of the Netherlands must make more drastic cuts to its greenhouse-gas emissions (see Nature http://doi.org/559; 2015). Given that climate lawsuits are increasingly being brought against governments, other countries would do well to heed the District Court's pioneer ruling.

The court declared that the current Dutch policy, which is expected to cut emissions by $17 \%$ by 2020 , was an infringement of the state's duty of care towards its citizens because of the severe consequences of climate change and the risk to the population.

The Dutch state is now obliged under private law to take adequate mitigation measures to avert the dangers associated with climate change. It must cut its emissions by at least $25 \%$ by 2020, relative to 1990 levels - the minimum target set by climate scientists (see also go.nature.com/nxhe5h).

Kai Purnhagen Wageningen University; and Erasmus University Rotterdam; the Netherlands.

kai.purnhagen@wur.nl

\section{Climate law: path paved for civil action}

The Lancet Commission on Health and Climate Change last month concluded that climate change is a risk to public health (N. Watts et al. Lancet http:// doi.org/56b; 2015). In the same week, a Dutch court ordered the government of the Netherlands to improve its reduction of greenhouse-gas emissions to protect the population from harm and to keep the country habitable by safeguarding the environment (see Nature http:// doi.org/559; 2015).

We suggest that this court order is closely studied by other countries. If governments do not act, they should expect lawsuits from families who lost relatives during, say, the heatwaves in Europe in 2003 or in Pakistan and India this year.

Yali Si Tsinghua University, China.

Herbert H. T. Prins Wageningen University, the Netherlands. yalisi@mail.tsinghua.edu.cn 